\title{
The Instrument Implementation of Two-tier Multiple Choice to Analyze Students' Science Process Skill Profile
}

\author{
Sukarmin $^{1}$, Ratnasari, D. ${ }^{2}$, Suparmi $^{3}$ \\ ${ }^{1,2}$ Science Education Department, Graduate Program of Sebelas Maret University, Indonesia \\ ${ }^{3}$ Physics Department, Graduate Program of Sebelas Maret University, Indonesia
}

Corresponding email: sukarmin67@staff.uns.ac.id

\begin{abstract}
This research is aimed to analyze the profile of students' science process skill (SPS) by using instrument two-tier multiple choice. This is a descriptive research that describes the profile of students' SPS. Subjects of the research were 10thgrade students from high, medium and low categorized school. Instrument twotier multiple choice consists of 30 question that contains an indicator of SPS. The indicator of SPS namely formulating a hypothesis, designing experiment, analyzing data, applying the concept, communicating, making a conclusion. Based on the result of the research and analysis, it shows that: 1) the average of indicator achievement of science process skill at high categorized school on formulating hypothesis is $74,55 \%$, designing experiment is $74,89 \%$, analyzing data is $67,89 \%$, applying concept is $52,89 \%$, communicating is $80,22 \%$, making conclusion is $76 \%, 2$ ). the average of indicator achievement of science process skill at medium categorized school on formulating hypothesis is 53,47\%, designing experiment is $59,86 \%$, analyzing data is $42,22 \%$, applying concept is $33,19 \%$, communicating is $76,25 \%$, making conclusion is $61,53 \%, 3$ ) the average of indicator achievement of science process skill at low categorized school on formulating hypothesis is $51 \%$, designing experiment is $55,17 \%$, analyzing data is $39,17 \%$, applying concept is $35,83 \%$, communicating is $58,83 \%$, making conclusion is $58 \%$.
\end{abstract}

Keywords: Science process skill; two-tier multiple choice

DOI: $10.20961 /$ ijpte.v2i0.19820 


\section{INTRODUCTION}

The aim of education and science education is to educate individual who can adapt to a different condition, thinking flexibly, asking actively, creatively and critically, being able to solve problems and to respect others' opinion (Aktamis \& Yenice, 2010). Physics learning process is truly aimed to develop students' thinking skill, provide knowledge and understanding, and evolve knowledge and technology (Depdiknas, 2006). Physics is an essential subject in the curriculum at school because of its contribution to the development of science and technology in society (Eraikhumen \& Ogumogu, 2014).

Indonesian education system has a standard of students' graduate competence. Graduate competency standard is a qualification of graduate competence that consists of attitude, knowledge, and students' skill. Those aspects must be fulfilled in one level of basic and middle education (Depdiknas, 2003)

In curriculum 2013 that is applied in Indonesia, teachers are demanded to be able in applying scientific approach. The learning process is conducted by using a scientific approach that consists of some activities such as observing, formulating questions, attempting or collecting data with various techniques, associating or analyzing or processing data, concluding and communicating the result that consists of conclusions to obtain knowledge, skill, and attitude. The success of learning process can be seen from an assessment conducted by students. The assessment in the learning process by using scientific approach must be able to measure the skills. Therefore, the assessment instrument of science process skill must be developed in some aspects such as the cognitive aspect of the two-tier test, students' self-assessment, classmates' assessment and work assessment (Wulandari, et al., 2015)

In curriculum 2013, it is explained that students' assessment in the learning process is quite related to thinking skill. Students' thinking skill in building new concept in science learning process can be trained through the development of science process skill. Science process skill is suitable for science learning process because it must be directed to activate students, to give direct experience to students and to train their thinking skill in the learning process (AAAS, 1989).

Science process skill is not handed skill using tools but it is a thinking skill by using science process. Therefore, the main tests can be conducted in written test in which it needs a tool to complete that main test (Tawil \& Liliasari, 2014). Science process skill does not include the assessment that will affect the useless learning process. Therefore, it needs to conduct an assessment that suitable for science process skill (Harlen, 2013).

The instrument of Two-tier Multiple Choice (TTMC) consists of 2 section. The first section (first tier) is similar to multiple questions. It consists of a questions item or an answer option, one of which is the correct answer and the rest are distractors. In the second section, students are asked to state the reason why they selected a particular option. The second section (second tier) of the test is a multiple choice format with options containing common student misconceptions identified in the literature or via interviews, or a multiple choice format where one of the options is open-ended (Karataş, et al., 2003). 
Through instrument of TTMC, students' process skill can be explored. In addition, teachers can also recognize students' understanding of the certain concept. Science process skill cannot be separated with concept understanding used in science learning process and its application. However, the importance of this skill must also be applied to another subject because the main aspect of the learning process is understanding informal education and daily life. This case becomes the reason for the importance of science process skill assessment (Harlen, 1999).

There are many former researchers who state the importance of science process skill in science learning process. The advantages of science process skill as follows; science process skill support students to improve scientific inquiry ability, improving students' verbal ability during discussion and interpretations, get results together in educational environments where students learn together, and make students' natural curiosity (Setlage \& Southerland, 2007). Science process skill is important in learning science. Therefore, it needs profile analysis of students' science process skill. The analysis uses assessment instrument of twotier multiple choice.

\section{METHOD}

This research is a descriptive research using a qualitative approach. The design of descriptive research uses a sample from experiment to document, to describe, and to explain whether there is a phenomenon or not. A qualitative approach is used to count the percentage of students' science process skill of each category school. Research subjects were 10th-grade students in the academic year of 2016/2017. There are 148 students from high, medium, and low categorized school in Surakarta. The category is based on the score of national examination at the latest four years. Data of science process skill is obtained from students' test using assessment instrument of two-tier multiple choice. Data that consists of the result of students' test is used to analyze the achievement of each indicator of science process skill. The indicators are formulating a hypothesis, designing experiment, analyzing data, applying the concept, communicating and making a conclusion.

\section{RESULT AND DISCUSSION}

Data from this research collected from students' answer using the two-tier multiple-choice instrument. The instrument consists of 30 questions with contains science process skill indicators and each indicator consist of 5 questions. Before tested to sample, instrument two-tier multiple choice analyzed its feasibility. If it is proper, the instrument is tested to 148 students from high, medium and low categorized school in Surakarta. The result of test analysis can be seen in Table 1.

Table 1. The indicator achievement of students' science process skill.

\begin{tabular}{|c|l|c|}
\hline \multirow{2}{*}{ School category } & \multicolumn{1}{|c|}{$\begin{array}{c}\text { Science Process Skill (SPS) } \\
\text { Indicator }\end{array}$} & $\begin{array}{c}\text { Achievement of science } \\
\text { process skill (\%) }\end{array}$ \\
\hline \multirow{2}{*}{ High } & Formulating a hypothesis & 74,55 \\
\cline { 2 - 3 } & Designing experiment & 74,89 \\
\cline { 2 - 3 } & Analyzing data & 67,89 \\
\cline { 2 - 3 } & Applying the concept & 52,89 \\
\hline
\end{tabular}




\begin{tabular}{|l|l|c|}
\hline \multirow{4}{*}{ Medium } & Communicating & 80,22 \\
\cline { 2 - 3 } & Making a conclusion & 76 \\
\hline \multirow{5}{*}{ Low } & Formulating a hypothesis & 53,47 \\
\cline { 2 - 3 } & Designing experiment & 59,86 \\
\cline { 2 - 3 } & Analyzing data & 42,22 \\
\cline { 2 - 3 } & Applying the concept & 33,19 \\
\cline { 2 - 3 } & Communicating & 76,25 \\
\cline { 2 - 3 } & Making a conclusion & 61,53 \\
\hline \multirow{5}{*}{} & Formulating a hypothesis & 51 \\
\cline { 2 - 3 } & Designing experiment & 55,17 \\
\cline { 2 - 3 } & Analyzing data & 39,17 \\
\cline { 2 - 3 } & Applying the concept & 35,85 \\
\cline { 2 - 3 } & Communicating & 58,83 \\
\cline { 2 - 3 } & Making a conclusion & 58 \\
\hline
\end{tabular}

Table 1 shows that the average percentage of indicator achievement of science process skill on high, medium and low categorized school. Based on data from table 1, it can be seen that the average achievement is various on each school. The difference of average percentage on each indicator can be seen in Figure 1.

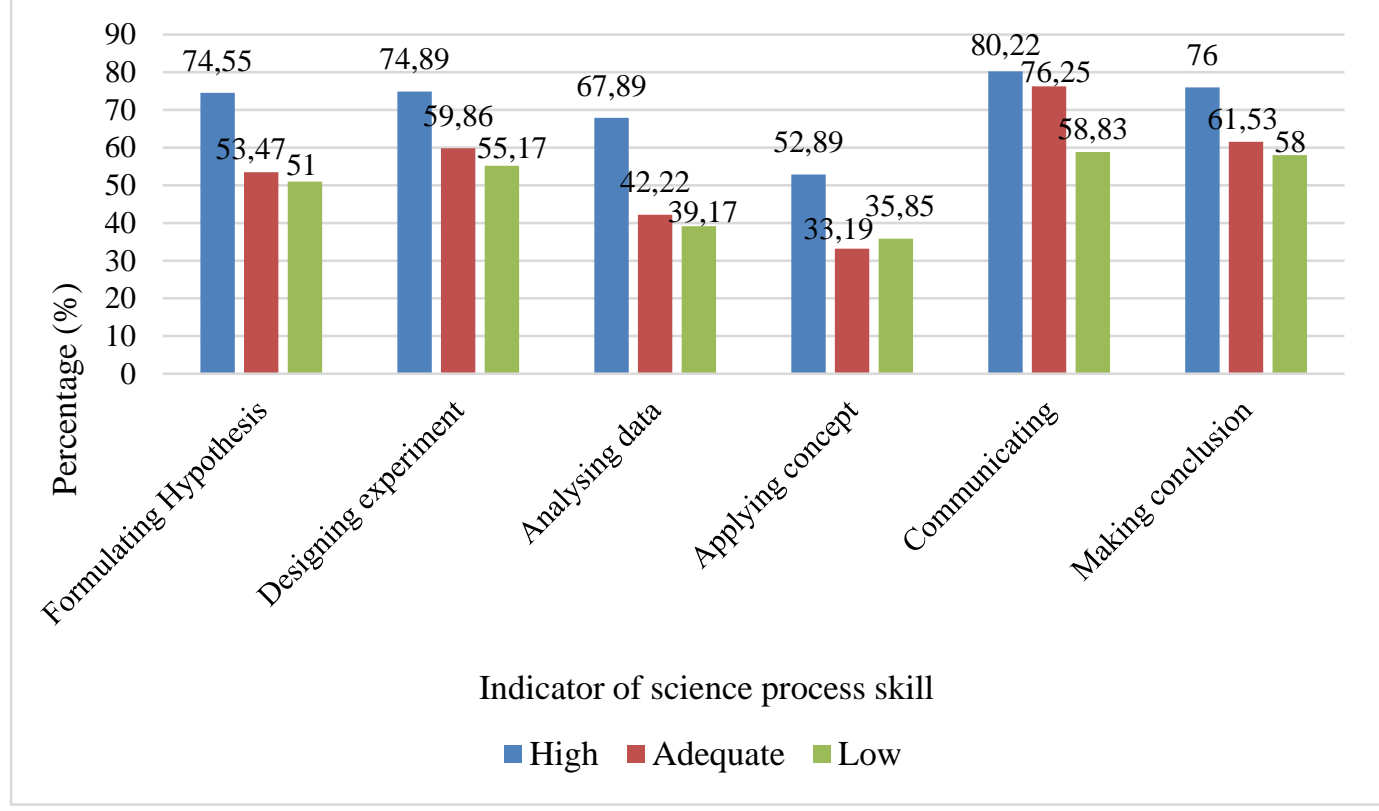

Fig. 1: The average percentage graphic of indicators achievement of science process skill on high, medium, and low categorized school.

Figure 1 shows the percentage graphic of the achievement average of indicators of science process skill on high, medium, and low categorized school. Based on the graphic at figure 1, the highest achievement is at high categorized school. The difference among three schools is not quite significant. On indicator of applying the concept, the achievement percentage at low categorized school is higher than at medium categorized school.

The lowest percentage indicator is on applying the concept. This indicator is related to students' conceptual understanding. Concept understanding and physics learning process are related to each other. Concept understanding makes students can transform knowledge become multiple representations and apply in daily life. 
Concept understanding from various physics concepts that have been obtained at schools can use as adequate basis and physics knowledge to the advance of the development of knowledge and technology. They are also expected to apply this knowledge in daily life (Omesewo, 2009).

Another indicator that has low achievement is a skill of analyzing data. This indicator is related to students' skill in doing lab work and applying concept on their own. Data of students' analysis is from lab work activity. It has been adapted from the concept they have learned. The low skill in analyzing data shows that students have not been able to conduct lab activity well. Science process skill is developed based on laboratory activity. Through laboratory activity, students gain meaningful learning, use science process skill, and understand the process on how they construct information in physics learning process.

The low percentage of the indicator is caused by competence test assessment that only focuses on concepts. In addition, teachers unable to develop an instrument that can be used to measure students' science process skill. The solution is giving training to the science teachers about science process skill and its indicators and assessments. Through the training, teachers expected can apply their knowledge in developing science process skill to the students (Sukarno, et al., 2013)

It needs an instrument that can assess students' science process skill. The assessment of students' science process skill is conducted by using an instrument of two-tier multiple choice. Two-tier multiple choice is 2 level test instruments that can solve the weakness of multiple choice instrument in which students only guess the answers. Two-tier multiple choice is more complicated than the common multiple choice. The first level (first tier) is almost same as traditional multiple-choice (Multiple Choice Question/MCQ), in which it usually concerns with knowledge aspect. The second level (two-tier) is almost same as traditional multiple choice but its purpose is to improve high-level skill and expressing reason skill (Adodo, 2013).

The instrument of two-tier multiple choice can be used to analyze the profile of science process skill by applying a scoring technique of Graded Response Model (GRM). GRM is one of the models that are developed to handle scoring on polytomous questions (De Ayala, 1993). The guidance of assessment instrument scoring of two-tier multiple choices by applying GRM is presented in Table 2 (Yamtinah et al., 2016).

Table 2. Scoring on the instrument of two-tier multiple choice

\begin{tabular}{llc}
\hline No & Assessment aspect & Score \\
\hline 1 & Do not choose any answer and reason, or wrong answer-wrong reason & 0 \\
2 & Wrong answer-correct reason & 1 \\
3 & Correct answer-wrong reason & 2 \\
4 & Correct answer-correct reason & 3 \\
\hline
\end{tabular}

The assessment of students' science process skill using GRM eases the teachers in scoring. Besides, teachers can recognize students' understanding through answers at the first and the second level. Therefore, this instrument can help teachers to make students' profile. 
Students' profile can support teachers' information to know how far the indicator has been achieved and what the students' difficulty is. Teachers can also conduct an analysis of indicator achievement. Therefore, teachers can make a profile of science process skill. Analysis of profile of science process skill is made with the help of Microsoft Excel. This kind of analysis is developed by a research from Wulandari et al., (2015) that analyzes students' understanding of hydrolysis material. Answer key, students' answer and indicator on each question are processed into Microsoft Excel to obtain indicator achievement of students' science process skill. Profile display of science process skill can be seen in Figure $2 \mathrm{a}$ and $2 \mathrm{~b}$.

\begin{tabular}{|c|c|c|c|c|}
\hline \multicolumn{5}{|c|}{ STUDENTS SCIENCE PROCESS SKILL PROFILE } \\
\hline \multicolumn{5}{|c|}{ Students' Identity } \\
\hline Name & $\mathrm{NN}$ & & & \\
\hline Number : & 7 & & & \\
\hline Class : & X MIA 1 & & & \\
\hline \multirow[b]{2}{*}{ Number } & \multirow[b]{2}{*}{ Score } & \multicolumn{3}{|c|}{ Indicator } \\
\hline & & Achieved & Have not achieved & Science process skill achieved \\
\hline 1 & 3 & $\begin{array}{l}\text { Being able to determine factors and the } \\
\text { relationship between variable that } \\
\text { affecting heat energy }\end{array}$ & 然 & Making conclusion \\
\hline 2 & 3 & $\begin{array}{l}\text { Being able to determine factors and the } \\
\text { relationship between variable that } \\
\text { affecting heat energy to increase } \\
\text { temperature }\end{array}$ & - & Making conclusion \\
\hline 3 & 1 & $\begin{array}{l}\text { Being able to determine factors affecting } \\
\text { increase of temperature }\end{array}$ & $\begin{array}{l}\text { Creat graphs the relationship between } \\
\text { temperature and heating time by taking } \\
\text { into independent variables and dependent } \\
\text { variables }\end{array}$ & - \\
\hline 4 & 3 & $\begin{array}{l}\text { Being able to design experiments and } \\
\text { explain the processes needed to determine } \\
\text { the heat relations with temperature } \\
\text { changes. }\end{array}$ & - & Designing experiment \\
\hline
\end{tabular}

Fig 2a: The example of display profile of students' conceptual understanding using Microsoft Excel program ( $1^{\text {st }}$ part or the beginning part)

\begin{tabular}{|c|c|c|c|c|}
\hline 28 & 3 & $\begin{array}{l}\text { Being able to formulate hypotheses based } \\
\text { on experimental objectives on the principle } \\
\text { of Black and apply basic concepts of the } \\
\text { Black principle. }\end{array}$ & & Formulating hypothesis \\
\hline 29 & 3 & $\begin{array}{l}\text { Being able to determine the state of ice } \\
\text { after receiving heat and apply the concept } \\
\text { of the influence of heat to phase change } \\
\text { of substances. }\end{array}$ & & Applying concept \\
\hline 30 & 3 & $\begin{array}{l}\text { Being able to determine the energy } \\
\text { absorbed by objects and apply the concept } \\
\text { of radiation. }\end{array}$ & & Analyzing data \\
\hline Name & & Total score & Science process skill category & \\
\hline \multirow[t]{11}{*}{$\mathrm{NN}$} & & 76 & HIGH & \\
\hline & & Academic score & 84.44 & \\
\hline & & & & \\
\hline & & \multicolumn{2}{|c|}{ Percentage of science process skill achieved } & \\
\hline & & Science process skill indicator & Percentage (\%) & \\
\hline & & Formulating hypothesis & 80 & \\
\hline & & Designing experiment & 80 & \\
\hline & & Analyzing data & 0 & \\
\hline & & Applying concept & 60 & \\
\hline & & Communicating & 80 & \\
\hline & & Making conclusion & 80 & \\
\hline
\end{tabular}

Fig. 2b: The example of display profile of students' conceptual understanding using Microsoft Excel program ( $2^{\text {nd }}$ part or the last part)

Figure $2 \mathrm{a}$ and $2 \mathrm{~b}$ shows the profile of students' science process skill. At table 2, it can be seen which indicators that have been achieved. Besides, the indicators of science process skill can also be seen. By the emergence of indicator on each 
number, the indicators' achievement can be counted. One indicator is measured with 5 questions. Therefore, the achievement percentage of each indicator will be $100 \%$ if students can correctly answer all the 5 questions. Based on the picture, students can be categorized into high, medium and low. The group of science process skill category can be seen in Table 3 .

\begin{tabular}{cc} 
Table 3. Category of students' science process skill \\
\hline Total score & $\begin{array}{c}\text { Category of science } \\
\text { process skill (SPS) }\end{array}$ \\
\hline $0-30$ & Low \\
$31-60$ & Medium \\
$61-90$ & High \\
\hline
\end{tabular}

Category of science process skill can be summed up to obtain the average of each category in one class. Through the average of each class, the class profile can be made. The class profile is used to recognize which class that has higher science process skill. By using the same steps, it can also be applied to the broader scale.

Students' profile can also be used to know students' achievement and their difficulty in learning physics. It will make teachers do a further attempt at the remedy (Wardani, et al., 2015). The instrument of two-tier multiple choice does not only function as an instrument to measure science process skill but also as a diagnostic instrument.

The instrument of two-tier multiple choice becomes an alternative instrument to measure students' science process skill. It can also be used to measure the level of students' thinking. Two-tier multiple choice is a model assessment that is useful to education. It can also help students to measure high level thinking skill and help teachers identify students' misconception (Adodo, 2013).

Science process skill has also a positive effect on students' achievement. The former researches show that there is a positive relationship between science process skill with academic success in science courses (Beaumont-Walters \& Soyibo, 2001; Farsakoglu, 2012, Delen \& Kesercioglu, 2012). Academic achievement and science process skill are related to the process of students' conceptual change. Therefore, it needs science process skill to develop high-level conceptual change. Science process skill can be separated from conceptual change and conceptual understanding (Karamustafaoglu, 2011). Science process skill can be seen as a factor that supports concept understanding because it relates to academic achievement.

\section{CONCLUSION}

Based on the result of the research and analysis, it shows that: 1) the average of indicator achievement of science process skill at high categorized school on formulating a hypothesis is $74,55 \%$, designing experiment is $74,89 \%$, analyzing data is $67,89 \%$, applying the concept is $52,89 \%$, communicating is $80,22 \%$, and making a conclusion is $76 \%, 2$ ). the average of indicator achievement of science process skill at medium categorized school on formulating a hypothesis is $53,47 \%$, designing experiment is $59,86 \%$, analyzing data is $42,22 \%$, applying the concept is $33,19 \%$, communicating is $76,25 \%$, and making a conclusion is 
$61,53 \%, 3)$ the average of indicator achievement of science process skill at low categorized school on formulating a hypothesis is $51 \%$, designing experiment is $55,17 \%$, analyzing data is $39,17 \%$, applying the concept is $35,83 \%$, communicating is $58,83 \%$, and making a conclusion is $58 \%$.

\section{REFERENCES}

Adodo, S. O. (2013). Effects of Two-Tier Multiple Choice Diagnostic Assessment items on Students' Learning Outcome in Basic Science Technology. Ondo State: Academic Journal of Interdisciplinary Studies, 2(2), 201-210.

Aktamis, H., \& N. Yenice. 2010. Determination of the science process skills and critical thinking skill levels. Procedia Social and Behavioral Sciences, 2 3282-3288.

American Association for the Advancement of Science (1967). Science-A Process Approach. Washington, D.C: American Association for the Advancement of Science.

Beaumont-Walters, Y., \& Soyibo, K. (2001). An Analysis of High School Students' Performance on Five Integrated Science Process Skills. Research in Science \& Technological Education, 19(2), 133-145. https://doi.org/10.1080/02635140120087687.

De Ayala, R. J. (1993). An Introduction to Polytomous Item Response Theory Models. Measurement and Evaluation in Counseling and Development, 25 127-189.

Delen, I., \& KesercioÇ§lu, T. (2012). How middle school students' science process skills affected by Turkey's national curriculum change? Journal of Turkish Science Education, 9(4), 3-9.

Departemen Pendidikan Nasional, 2003. Undang-Undang Nomor 20 Tahun 2003, Tentang Sistem Pendidikan Nasional. Jakarta: Depdiknas

Depdiknas. (2006). Kurikulum Tingkat Satuan Pendidikan (KTSP). Jakarta: Depdiknas.

Eraikhuemen, L \& Ogumogu, A.E. (2014). An assessment of secondary school physics teachers' conceptual understanding of force and motion in Edo South senatorial district. Academic Research International, 5(1), p. 253262

Farsakoglu, O. F., Sahin C., \& Karsh, F. (2012). Comparing science process skills of prospective science teachers: A cross-sectional study. Asia-Pacific Forum on Science Learning and Teaching 13(1), 1-7.

Harlen, W. (1999). Purposes and Procedures for Assessing Science Process Skills. Assessment in Education: Principles, Police \& Practice, 6 (1), 129-141.

Harlen, W. (2013). Assessment \& Inquiry-Based Science Education: Issues in Policy and Practice. Trieste: The Global Network of Science Academies Science Education Programme.

Karamustafaoğlu, S. (2011). Improving the science process skills ability of science student teachers. Eurasian Journal of Physics and Chemistry Education, 3(1), 26-38. 
Karataş, F.Ö., Köse, S. \& Coştu, B. (2003). Öğrenci yanılgılarını ve anlama düzeylerini belirlemede kullanılan iki aşamalı testler. Pamukkale Üniversitesi Ĕ̈itim Fakültesi Dergisi, 1 (13), 54.

Omosewo, E.O. (2009). Views of physics teachers on the need to train and retrain Physics teachers in Nigeria. African Research Review, 3 (1), p. 314-325.

Settlage, J., \& Southerland, S. A. (2007). Teaching science to every child: Using culture as a starting point. New York: Taylor \& Francis.

Sukarno, Permanasari, A., \& Hamidah, I. (2013). The Profile of Science Process Skill ( SPS ) Student at Secondary High School ( Case Study in Jambi ). International Journal of Scientific Engineering and Research (IJSER), 1(1), 79-83. Retrieved from www.ijser.in

Tawil \& Liliasari. (2014). Keterampilan-ketrampilan Sains dan Implemantasinya Dalam Pembelajaran IPA. Makasar: Badan Penerbit Universitas Negeri Makasar.

Wardani, R.K., Yamtinah, S., Mulyani, B. (2015). Instrumen Penilaian Two-Tier Test Aspek Pengetahuan untuk Mengukur Keterampilan Proses Sains (KPS) pada Pembelajaran Kimia untuk Siswa SMA/MA Kelas X. Jurnal Pendidikan Kimia (JPK), 4 (4), 156-162.

Wulandari, R.R.A., Yamtinah, S. Saputro, S. (2015). Instrumen Two Tier Test Aspek Pengetahuan Untuk Mengukur Ketrampilan Proses Sains (KPS) pada Pembelajaran Kimia Untuk Siswa SMA/MA Kelas XI. Jurnal Pendidikan Kimia (JPK), 4 (4), 147-155.

Yamtinah, S., Haryono, Saputro, S., Mulyani, B., Suryadi, BU. (2016). Item Discrimination of Two-Tier Test on Hydrolysis of Salt. Proceeding International Conference on Educational Research and Evaluating (ICERE), 360-365. 
International Journal of Pedagogy and Teacher Education (IJPTE) (Vol. 2 | Focus Issue-January 2018) 